\title{
FACTORS THAT INFLUENCE GROSS DOMESTIC PRODUCT IN OIL EXPORTING COUNTRIES \\ MEMBERS OF THE ORGANIZATION OF ISLAMIC COOPERATION (OIC) IN THE PERIOD 1985-2016
}

\author{
Imaduddin zakiy \\ Student Program S1-Islamic Economics Faculty of Economics and Business- \\ University of Airlangga \\ E-mail: imaduddin.zakiy-13@feb.unair.ac.id
}

Eko Fajar Cahyono

Department of Islamic Economics-Faculty of Economics and Business-University of Airlangga

E-mail: ekofajarc@feb.unair.ac.id

\begin{abstract}
The aim of this research is to analyze the impact of world oil prices, the dollar exchange rate, and inflation on economic growth in oil exporting countries at the organization of Islamic cooperation. The purposive sampling method used to Determine the 5 nation that fulfill the requirements needed. The Data used in this research is secondary Data Obtained from various international statistics institute. This study uses a quantitative approach and panel regression analysis of data that combines time series of data and crosssection data.

The result of research with Fixed Effect estimation models shows that the impact of world oil prices, the dollar exchange rate, and inflation simultaneously have a significant effect on economic growth in oil exporting countries at the organization of Islamic cooperation. The other result shows that inflation partially does not have impact on economic growth in oil exporting countries at the organization of Islamic Cooperation, meanwhile other independent variables of the USD exchange rate and world oil prices partially have positive and significant effect on economic growth in oil exporting countries at the organization of Islamic cooperation during the period 1985-2016.
\end{abstract}

Keywords: World Oil Prices, Oil Exporting Countries, GDP, USD Exchange Rate, Inflation 


\section{Introduction}

Economic growth is one indicator that is very important in the analysis of the economic development that occurs in a country. Where economic growth shows the extent to which economic activity would generate additional income of the people in a given period. Economic activity is basically a process of the use of factors of production to produce output, then this process will in turn generate a stream of remuneration of the factors of production are owned by society. With the economic growth it is expected that public revenue as owners of production factors will also increase.

In the point of view of Islam, the economic growth is not only material but also runs a priority element of morality and spirituality because in Islam human is not just going through life alone but the human world will be resurrected in the Hereafter. Such an attitude from the first well is already integrated in the life of a social, political or economic (Mannan, 1997).

Organization of Islamic Cooperation abbreviated as OIC is an international organization consisting of non-military Islamic countries and countries with a Muslim majority population. Currently the 57-nation OIC Islamic or Muslim majority in Asia and Africa, The main objective of the establishment of the OIC to enhance Islamic solidarity among member countries, coordinate cooperation between countries members, in support of peace and international security, and protecting the holy places of Islam and help fight the formation of an independent Palestinian state and sovereign.

In addition to the main goal, the Islamic suggestion for ta'awun or cooperate and mutual help among the people of the prophet Muhammad in his favor. for those who were able to rescue his brother from bad deeds and efforts as mutually reinforcing efforts, then surely this is a form of aid that must be done to fellow Muslims. As Allah says in Surah Al-Maidah verse 2:

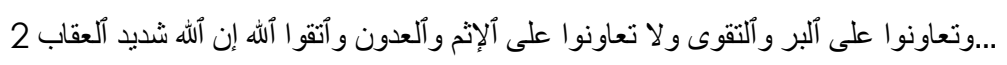
... wa ta'awanu'alal-Birri-Taqwa wat wa la ta'awanu'alal-Seismic wal-'udwān (i) wattaqullāh (a) Innallaha syadídul-'iqāb (i) 
It means: "... And cooperate in righteousness and piety, but do not cooperate in sin and aggression. And fear Allah ; indeed, Allah is severe in penalty. "(Ministry of Religious Affairs, 2012).

In the economy, the OIC member countries have a potential economic resources in different fields and sectors such as agriculture, energy, mining and human resources, and these countries is a strategic area for large trades. In 2016 the OIC countries listed have a population of 23.4 percent of the total world population. With a total GDP amounted to 15.3 percent of total world GDP OIC member countries accounted for only 8.4 percent of global production in 2016. According to data from SESRIC (The Statistical, Economic and Social Research and Training Center for Islamic Countries) in 2017, from 2012 to 2016 the state OIC member-states only raise its share in world output of 0.3 percent at 15.3 percent at the end of 2016. While the United States and China have a number of larger share of $(15$.

The structure of the GDP of the OIC member states are divided into four major sectors, namely agriculture, industry (non-manufacturing), industry (manufacturing), and services. A large part of agriculture in the total GDP of the OIC countries has decreased gradually from $11.8 \%$ in 2000 to $11.0 \% \%$ in 2015 in line with the development of non-manufacturing industries. State agriculture is the largest contributor with 60.2 percent Somalia and countries with agriculture under 1 percent is 0.2 percent Qatar, Bahrain 0.3 percent, 0.6 percent and Kuwait. The industrial sector recorded an average 36.7 percent of the total GDP of the member states in 2015. And the largest sector is the services sector with an average of 52.8 percent of the total GDP of the OIC member countries.

Inflation is a rise in prices that occur continuously. According Rahardja (2008: 54) inflation is rising prices of goods that are general and ongoing. Based on these definitions, there are three components that must be met in order for a state can be said to have occurred inflation, ie price increases, general and ongoing inflation or rising prices cause a bad effect on trade. The rise in prices led to the country's goods can not compete in the international market with exports declining. In contrast, the prices of domestic production is higher as a result of inflation causes the imported goods become relatively cheaper then imports will be more done.

Inflation can also be considered as a monetary phenomenon due to the decrease in the exchange rate against a commodity monetary calculations. Inflation can be measured with an inflation rate that is the rate of change of the 
general price level (Karim, 2007: 135). Very serious inflation may reach the level of a few hundred or thousand percent in a year (Sukirno, 2007: 15).

Economic growth and development is closely related to inflation, and inflation or price level is very sensitive to production activities. In the production process, energy is one of the fundamental input. Energy consumption to increase from year to year. The world of the total energy consumption has increased every year. Daily activities can not be separated from energy use. Oil is a vital energy source for the production process in a macro and micro scale, so that the economy will depend on world oil prices.

According to data from the BP Statistical Review of World Energy 2017, of total world energy consumption 38 percent fulfillment derived from oil. While the rest, filled with natural gas, coal and nuclear. Meanwhile in Islamic countries with oil export commodity that OPEC has the demand for energy is supported by crude oil to 285.5 million tonnes in 2011 , rising at the rate of consumption of 328.9 million tons in 2016. This shows how great the need and dependence on crude.

Many of the factors that encourage consumption terms, terms of exchange rates, on the international market, the US dollar is used as the main exchange for oil trade transactions.It is like two sides of a coin, one side of the course to facilitate transactions that occur but on the other hand the use of the US dollar made a crack on the stability of oil prices. When the level of the US dollar has appreciated it will make the price of oil more expensive for importing countries and leading to a reduced demand for oil in the country, and the opposite is true in the exporting country when the level of the exchange rate of the dollar depreciates in the currency they require that they should keep the cost of production below the selling price.

\section{Formulation of the problem}

Based on the background described above, the formulation of the problem for this study are:

1. Is the Oil Price significant effect on the Gross Domestic Product in the world oil exporting country Organization of Islamic Cooperation (OIC) in the period 19852016 ?

2. Do Exchange Rates USD a significant effect on the Gross Domestic Product in the world oil exporting country Organization of Islamic Cooperation (OIC) in the period 1985-2016? 
3. Is inflation a significant effect on the Gross Domestic Product in the world oil exporting country Organization of Islamic Cooperation (OIC) in the period 19852016 ?

4. Is the world oil prices, the USD exchange rate and inflation simultaneously significant effect on the Gross Domestic Product in the world oil exporting country Organization of Islamic Cooperation (OIC) in the period 1985-2016?

\section{Litterature Review}

According to Kuznets in Todaro (2000: 144), economic growth has a meaning as an increase in long-term economic capacity of a country to provide economic goods to the population. Economic growth is usually measured by the GDP data or income or the value end of the market (total market value) of goods and services end (final goods and services) resulting from an economy over a certain period of time. Gross Domestic Product (GDP) can be interpreted as the final value of goods and services produced by the various production units in the territory of a country within a period of one year.

In the Islamic view, economic growth is seen as an outline of a development and the development of human well-being. As quoted from Ahmad (1997) explained that economic growth is not merely material but also spiritual with the presence of the concept of justice the distribution of income and wealth to every individual in the whole generation, remove usury, and requires zakat. The statement was based on the word of Allah in the letter At-Tauba paragraph 103:

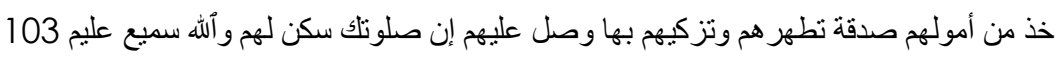

khuż min amwālihimsadaqatan tuTahhiruhum tuzakkihim Biha wa wasalli 'alaihim, innasalātaka sakanul lahum, Wallahu samīun 'alim

Meaning: "Take alms of their wealth, the charity that you cleanse and purify them and pray for them. Surely prayer you that (a) peace for their souls. And Allah is Hearing, Knowing. "(Ministry of Religious Affairs, 2012).

Since the start of the industrial revolution, fossil fuels began to be used on a large scale and is used to drive the economy. Until now, crude oil is still the biggest source of energy, although today many countries that dig deeper into the potential of renewable energy, dependence on crude oil can not be ignored.

Paul Krugman and Obstfeld (2004) describe the exchange rate as the price of a currency is measured or expressed in another currency. Exchange rate reform according to them can be divided into two, namely depreciation and 
appreciation. Each of the economy of a country has its exchange rate regime is different that determined by the monetary authorities of each country with a favorable consideration of their economic growth Corden (2002).

Understanding inflation by Russell Sobel et. al. (2009) is an increase in the general level of prices of goods and services. Inflation itself is not a phenomenon in which the price increases in the short term, but that inflation showed an increase in prices that took place in a relatively long period of time (Boyes and Melvin, 2008).According to Mankiw (2003: 77) inflation is an increase in the overall price level and the time-sensitive area. In some cases, inflation can take place in a prolonged and outside of government control. The inflation rate can be calculated by calculating the percentage increase / decrease in the price level from year to year (or month-to-month). The following equation models

$$
\frac{\text { IHKn- IHKo }}{\text { IHKo }} \times 100 \%
$$

Information:

\section{IHKn : CPI this period}

IHKO : CPI last period

From the calculations above formula can know what level of inflation in OIC countries of the Petroleum Exporting using the Consumer Price Index calculation period 1985-2016 were obtained from data.worldbank.org

\section{Hypotheses and Model Analysis}

Based on the background, the formulation of the problem and the theoretical basis that has been described, in this study can be formulated hypothesis:

1. World oil prices have a significant effect on the Gross Domestic Product in the oil exporting OIC countries in the period 1985-2016.

2. The exchange rate against the USD significantly influence the Gross Domestic Product in the oil exporting OIC countries in the period 1985-2016.

3. Inflation significant effect on the Gross Domestic Product in the oil exporting OIC countries in the period 1985-2016.

4. World oil prices, the USD exchange rate and inflation simultaneously significant effect on the Gross Domestic Product in the oil exporting OIC countries in the period 1985-2016.

While the analytical model used in this study are as follows:

$Y=a+\beta 1 W O P+\beta 2 E X C+\beta 3 I N F+\mu$ 


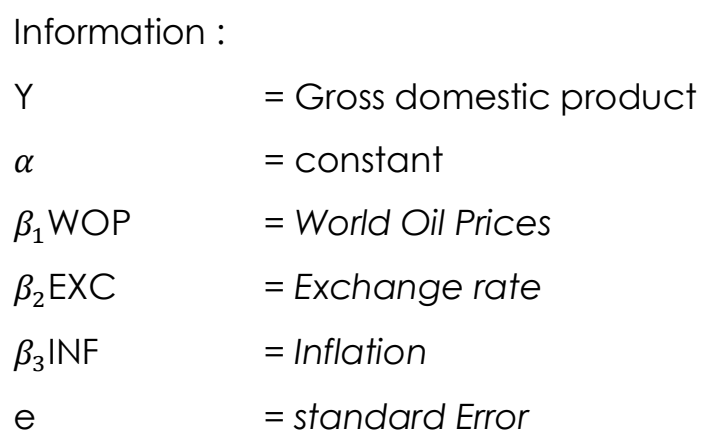

\section{Research Methods}

\section{Research approach}

The approach used in this study is a quantitative approach with panel data regression analysis method. Panel data regression method is used to determine whether there is a significant influence of the independent variables of more than one dependent variable, this data is a combination of time series and cross section.

\section{Operational definition}

a. Gross domestic product

According to McEachern (2000: 146), meaning that GDP measures the market value of final goods and services produced by resources that are within a country during a certain period, usually one year. GDP can also be used for studying the economy over time or to compare several economies at a time. GDP variable data used in this study is a Constant 2010 GDP data in USD and is obtained from the official website of the World Bank on a quarterly time series observation periods ranging from 1985 to 2016 , with an adjustment in US \$.

b. Inflation

Inflation is a phenomenon common to an increase in the price of goods and services within a certain period. The calculation of the inflation rate is obtained based on the Consumer Price Index. The use of inflation because the $\mathrm{CPI}$ in calculating the CPI measures the average price of goods and services purchased by the average consumer in a country with the following equation:

$$
I N F n=\frac{\text { IHKn }- \text { IHKo }}{\text { IHKo }} \times 100 \%
$$

Information:

INFN : Inflation Period $n$

IHKn : Consumer Price Index period $n$ 
IHKO : Consumer Price Index period $n-1$

Data variable inflation rate in the period 1985-2016 were used in this study were obtained from the publication of the report the rate of inflation on the website World Bank in percentage units.

c. World Oil Prices

The world oil price variable data used in this study used the price of OPEC oil production with an annual intervals in the observation period ranging from 1985 to 2016 expressed in US \$ / Barrel.

d. Level Exchange Rates

The exchange rate is the price level of a country's currency are translated into the currency of another country to become an international monetary system that facilitates trade and investment between countries. Meanwhile Krugman (2004) describe the exchange rate as the price of a currency is measured or expressed in another currency. Exchange Rate variable data used in this study was obtained from the official website of the World Bank in the period of observation began in 1985 until 2016.

\section{Types and Sources of Data}

Data used in this research is secondary data panel. Secondary data in this study is the historical data that have been published by several agencies obtained by researchers at the official website such as the World Bank, data.worldbank.org, Energy Information Administration in www.eia.gov and the Statistical, Economic and Social Research and Training Center for Islamic Countries on its official website www.sesric.org, The data used in this study a yearly time series data, the research period starting from 1985 to 2016.

\section{Population And Sample}

Population is a generalization region consisting of subjects that have certain characteristics and the quantity of applied researchers to be learned and conclusions drawn (Anshori and Iswati, 2009: 92). The population used in this study is a member country of the Organization of Islamic Cooperation and incorporated in the Organization of the Petroleum Exporting Countries 1985-2016 period.

Sampling technique used is purposive sampling. Sampling is purposive sampling technique with a certain consideration (Anshori and Iswati, 2009: 92). The technique of taking this way aims to achieve the expected limitation of this study. Samples are countries that have the largest oil export commodity value and provide data that is not zero in the period 1985-2016 the number of five states. 


\section{Data analysis technique}

\section{Panel Data Regression Analysis}

This study uses panel data regression analysis techniques. Data panel is a combination of time series data with cross section data. Data time series data such as the value of one or more variables for one period. Cross section that is the value of one or more variables are drawn from several units of samples in the same time period (Gujarati, 2013: 235). According to Gujarati (2004: 559-603), there are three methods that can be used to estimate the model with panel data regression is Pooled Least Square (PLS), Fixed Effects Model (FEM) and Random Effects Model (REM).

1. Pooled Least Square. (PLS)

This method simply combines all data time series and cross section. The panel data model approach Pooled Least Square (PLS) is as follows (Gujarati, 2004: 640):

$$
Y_{i t}=\beta_{1}+\beta_{2} X_{2 i t}+\beta_{3} X_{3 i t} \ldots+\beta_{n} X_{n i t}+U_{i t}
$$

\section{Fixed Effect Model(FEM)}

Definition of fixed effect method is a model with a different intercept for each subject, but each intercept or slope than any subject does not change over time. Here is a fixed effect model with the addition of a dummy variable technique (Gujarati, 2004: 642):

$$
Y_{i t}=\alpha_{1}+\alpha_{2} D_{2}+\cdots+\alpha_{n} D_{n}+\beta_{2} X_{2 i t}+\cdots+\beta_{n} X_{n i t}+u_{i t}
$$

3. Random Effect Model(BRAKE)

In the FEM using the addition of a dummy variable in the model can reduce the degree of freedom if we have several cross-section data which will reduce the efficiency of the parameters to be estimated. Random Effect Modela disturbance estimation technique uses the term to represent ignorance of the actual model, but uses a dummy variable. The panel data model with random effects approach is as follows (Gujarati, 2004: 647):

$$
Y_{i t}=\beta_{1}+\beta_{2} X_{2 i t}+\cdots+\beta_{n} X_{n i t}+\varepsilon_{i t}+u_{i t}
$$

\section{Selection of Panel Data Regression Model Estimation}

Selection of the panel data estimation models using $F$ (Chow test) and Hausman test. Test F (Chow Test) is a test method to determine the method of pooled least square (PLS) with fixed effect model (FEM), whereas the Hausman test 
is used to determine the method of fixed effect model (FEM) with a random effect model (REM).

1. Chow test

According toWidarjono (2005: 88), the form of test formula F (test chow) used in determining the method of the pooled least square (PLS) with fixed effect model (FEM) is as follows:

$F=\frac{R_{u r}^{2}-R_{r}^{2} /(m)}{\left(1-R^{2}{ }_{u r}\right) /(n-k)}$

With the caption:

$R 2 R=R^{2}$ Pooled models Least Square

R2ue $\quad=R^{2}$ Fixed Effect models Modem

$\mathrm{m} \quad=$ The number of variables teretriksi

$\mathrm{n} \quad=$ Number of samples

$\mathrm{k} \quad=$ Number varaibel explanatory

The hypothesis used in the F test (test chow) are:

$\mathrm{HO}=$ Pooled Least Square (PLS)

$\mathrm{H} 1$ = Fixed Effect Model(FEM)

Criteria for making the decision is if the significance value $<0.05$ then $\mathrm{HO}$ is rejected, the estimation technique used is the model FEM and if the significance value> 0.05 then $\mathrm{HO}$ is accepted, then the estimation technique used is the PLS model.

2. Hausman test

Hausman test is used to select the method of fixed effect model (FEM) with the method of random effect model (REM), which was obtained through a study Hausman test EViews command, contained in the directory panel (Widarjono, 2005: 272). The hypothesis used in the Hausman test is:

$\mathrm{HO}=$ random effect model (REM)

$\mathrm{H} \mathrm{l}=$ fixed effect model (FEM)

Criteria for making the decision is if the significance of the Chi Square $<0.05$, then $\mathrm{HO}$ is rejected, so the model fixed effect model (FEM) is more appropriate to use and if the significance of the Chi Square> 0.05 , then $\mathrm{HO}$ is accepted, so that the model random effect model (REM) is more appropriate to use.

\section{testing Statistics}

\section{1. t test}

The t-test is a test to each of the independent variables on the dependent variable to determine the significance of the effect. Test test variable t see partially. 
HO: The independent variables did not significantly affect the dependent variable

$\mathrm{H1}$ : The independent variables significantly influence the dependent variable

\section{2. test $F$}

$F$ test is a test of all independent variables on the dependent variable to determine the significance of the effect. $T$ test saw test variables simultaneously or over.

HO: variable independent simultaneously no significant effect on the dependent variable.

$\mathrm{H1}$ : variable independent simultaneously significant effect on the dependent variable.

\section{3. interpretation Value $R^{2}$}

Interpretation of the value of the coefficient of determination or interpretation of an interpretation which is used to measure the effect of the independent variable on the dependent variable of a model in the study. Range determination coefficient ranges between zero and one $(0<<1)$. A value that indicates zero or close to zero, indicating that the lack of ability or the independent variables to explain the dependent variable or can be called very limited ability of the independent variable and shows the model used less precise. If the value indicates one or close to one, indicating that the independent variables was able to explain the dependent variable to provide the required information and means that the model used in the study is appropriate. $R^{2} R^{2} R^{2} R^{2}$

\section{Result and Discussion}

Descriptive statistical analysis in this study aims to outline an overview of the variables used in this study, the gross domestic product, world oil prices, exchange rates and inflation usd.

table 1

Descriptive statistics

\begin{tabular}{|c|l|l|}
\hline PDB & mean & 25.60772 \\
\hline
\end{tabular}


Source: Eviews $10 \mathrm{SV}$

\begin{tabular}{|l|l|c|}
\hline \multirow{4}{*}{} & maximum & 27.26080 \\
\cline { 2 - 3 } & Minimum & 22.82930 \\
\cline { 2 - 3 } & Std. Dev. & 1.287704 \\
\hline \multirow{4}{*}{ WOP } & mean & 3.467275 \\
\cline { 2 - 3 } & maximum & 4.695500 \\
\cline { 2 - 3 } & Minimum & 2.508000 \\
\cline { 2 - 3 } & Std. Dev. & 0.703056 \\
\hline \multirow{5}{*}{ INF } & mean & 10.60750 \\
\cline { 2 - 3 } & maximum & 72.84000 \\
\cline { 2 - 3 } & Minimum & -11.69000 \\
\cline { 2 - 3 } & Std. Dev. & 13.32850 \\
\hline \multirow{5}{*}{ EXC } & mean & 4.491619 \\
\cline { 2 - 3 } & maximum & 10.33900 \\
\cline { 2 - 3 } & Minimum & -0.112300 \\
\cline { 2 - 3 } & Std. Dev. & 2.508223 \\
\hline
\end{tabular}

\section{Selection of Panel Data Regression Model}

For the first estimate made Pooled Least Square model estimate and the second estimate to estimate a model Fixed Effect Model, after the results of the estimation model chosen, the next step is to test the model estimation are selected with Chow Test or Test of F-statistics. Hypotheses are formed in the Chow test is as follows:

H0: Model Pooled Least Square

H1: Fixed Effect Model

table 2

Chow test

Redundant Fixed Effects Tests

Pool: POOL01

Test cross-section fixed effects

\begin{tabular}{lrrr}
\hline \hline Effects Test & Statistic & d.f. & Prob. \\
\hline \hline Cross-section F & 2025.327238 & $(4,152)$ & 0.0000 \\
Cross-section Chi-square & 639.118234 & 4 & 0.0000 \\
\hline \hline
\end{tabular}

Source: Eviews $10 \mathrm{SV}$, the data is processed.

Based on the results of testing the F-statistic above results obtained probability value (Prob.) On Cross-section F of 0.0000 which has a value below the significance level of five percent or 0.05 so that $\mathrm{HO}$ rejected and $\mathrm{HI}$ accepted. 
Based on the test results, the panel data regression estimation model Pooled Least Square is not appropriate and the model chosen is a fixed effect estimation model for use in research.

table 3

Fixed Effect Model

\begin{tabular}{|c|c|c|c|c|}
\hline \multicolumn{5}{|c|}{$\begin{array}{l}\text { Dependent Variable: } Y \text { ? } \\
\text { Method: Pooled Least Squares } \\
\text { Date: } 10 / 07 / 18 \text { Time: } 18: 00 \\
\text { Sample: } 19852016 \\
\text { Included observations: } 32 \\
\text { Cross-sections included: } 5 \\
\text { Total pool (balanced) observations: } 160\end{array}$} \\
\hline Variable & Coefficient & Std. Error & t-Statistic & Prob. \\
\hline $\mathrm{C}$ & 24.09744 & 0.067058 & 359.3496 & 0.0000 \\
\hline $\mathrm{X} 1$ ? & 0.277285 & 0.019864 & 13.95905 & 0.0000 \\
\hline$X 2 ?$ & -0.000516 & 0.001142 & -0.451833 & 0.6520 \\
\hline X3? & 0.123414 & 0.011073 & 11.14582 & 0.0000 \\
\hline \multicolumn{5}{|l|}{ Fixed Effects (Cross) } \\
\hline ALJAZAIR--C & 0.004418 & & & \\
\hline GABON--C & -2.541626 & & & \\
\hline NIGERIA--C & 0.044939 & & & \\
\hline IRAN--C & 1.000344 & & & \\
\hline \multirow[t]{2}{*}{ ARAB--C } & 1.491925 & & & \\
\hline & Effects Sp & cification & & \\
\hline \multicolumn{5}{|c|}{ Cross-section fixed (dummy variables) } \\
\hline R-squared & 0.987152 & \multicolumn{2}{|c|}{ Mean dependent var } & 25.60772 \\
\hline Adjusted R-squared & 0.986560 & \multicolumn{2}{|c|}{ S.D. dependent var } & 1.287704 \\
\hline S.E. of regression & 0.149285 & \multicolumn{2}{|c|}{ Akaike info criterion } & -0.917206 \\
\hline Sum squared resid & 3.387495 & \multicolumn{2}{|c|}{ Schwarz criterion } & -0.763447 \\
\hline Log likelihood & 81.37647 & \multirow{2}{*}{\multicolumn{2}{|c|}{$\begin{array}{l}\text { Hannan-Quinn criter. } \\
\text { Durbin-Watson stat }\end{array}$}} & -0.854770 \\
\hline F-statistic & 1668.322 & & & 0.454559 \\
\hline Prob(F-statistic) & 0.000000 & \multicolumn{2}{|c|}{ Durbin-Watson stat } & \\
\hline
\end{tabular}

Source: Eviews $10 \mathrm{SV}$, the data is processed

Based on Table 4 results Pooled Least Square (PLS) may be written form the linear equation as follows:

GDP $=24.09744+0,277285 \mathrm{WOP}-0.000516 \mathrm{INF}+0.123414 \mathrm{EXC}$

\section{PARTIAL TEST (TEST-t)}

T-statistics test or partial test is used to see the effect of each independent variable on the dependent variable. Here is a hypothesis formed:

HO : No independent variable partial effect on the dependent variable.

$\mathrm{H} 1$ : Partial effect of independent variables on the dependent variable. 
Interpretation of the partial test by looking at the probability of t-statistics and the level of significance. If the probability value is less than the significance level was set then $\mathrm{HO}$ rejected and $\mathrm{H} 1$ accepted. Partial assay can be performed on the results of the regression estimation model. Based on the estimation model table 3 there are two of the three independent variables were tested, namely Oil Price (WOP) and Exchange Rate (EXC) which have a significant effect partially to the variable Gross Domestic Product (GDP) with a significance level of 5 per cent (0.05)

\section{SIMULTANEOUS TEST (TEST F)}

Test f-statistics or simultaneous test is used to see the effect of the three independent variables together on the dependent variable. The third variable is the Oil Price (WOP), inflation (INF) and Exchange Rate (EXC) were tested together to Gross Domestic Product (GDP). Here is a hypothesis formed:

$\mathrm{HO}: \mathrm{BO}=\beta 1=\beta 2=\beta 3=\beta 4=\ldots \beta \mathrm{K}=0 \rightarrow$ independent variables simultaneously has no effect on the dependent variable.

$\mathrm{Hl}: \mathrm{BO} \neq \beta 1 \neq \beta 2 \neq \beta 3 \neq \beta 4 \neq \ldots \beta \mathrm{K} \neq 0 \rightarrow$ simultaneously independent variables affect the dependent variable.

Simultaneous interpretation test by looking at the probability of t-statistics and the level of significance. , If the probability value is less than the significance level was set at 5 percent (0.05) $\mathrm{HO}$ is rejected and $\mathrm{HI}$ accepted. F-statistics test can be performed on the results of the regression estimation model. Based on Table 3 the results of the estimation model is getting f-statistics Probability of 0.0000 which is less than the predetermined significance which is 5 per cent $(0.05)$. With this the $\mathrm{H} 1$ accepted it demonstrates that world oil prices, the USD exchange rate and inflation simultaneously influence on gross domestic product in the world's oil exporting country Organization of Islamic Cooperation (OIC).

\section{Interpretation of the coefficient of determination R2}

Interpretation of the coefficient of determination contained in any estimation models do. The coefficient of determination used to measure the ability of independent variables in explaining the dependent variable. The smaller the value of R2, the smaller is also the ability of independent variables in influencing and explaining the dependent variable. Based on Table 3 the value of the coefficient of determination (R2) of0.987152 (98.71\%). Valuethe coefficient of determination is explained that the independent variables that world oil prices, inflation and the exchange rate may explain the dependent variable is the gross domestic product 
amounted to 98.71 per cent while the remaining 1.29 percent are other variables that are not included in this study.

\section{DISCUSSION}

\section{Oil price and GDP}

Based on the results of the panel data regression variables significantly influence world oil prices with a positive relation to Gross Domestic Product. It is based on the value of the variable probability of 0.0000 which is smaller than the significance level of 5 percent. This positive relationship between GDP and world oil prices are based on the positive value of variable coefficients 0277.

Based on these results concluded that the oil-exporting countries that are members of the OIC, the Gross Domestic Product of oil exporting countries depend on the level of world oil prices.

\section{Inflation and GDP}

Based on the results of the panel data regression inflation variable has no effect on the Gross Domestic Product. It is based on the value of the variable probability of 0652 that is greater than the significance level of 5 percent.

Based on these results concluded that the oil-exporting countries that are members of the OIC, inflation does not have a significant impact on the Gross Domestic Product of oil exporting countries of this.

\section{Exchange Rate and the Gross Domestic Product}

Based on the results of the panel data regression variable USD exchange rate have significant influence with a positive relationship to Gross domestic product, It is based on the value of the variable probability of 0.0000 which is smaller than the significance level of 5 percent. Positive correlation between gross domestic product and the USD exchange rate based on the positive value of variable coefficients 0123.

Based on these results concluded that the oil-exporting countries that are members of the OIC, the gross domestic product of oil-exporting countries is dependent on the intensity of the local exchange rates against the US dollar.

\section{Conclusions and Suggestions}

Based on the results of the analysis and research hypothesis testing as well as a discussion of the effect of oil prices, inflation and the exchange rate of the gross domestic product in oil-exporting countries organization of Islamic cooperation 1985-2016 period, it can be concluded as follows: 
1. World oil prices have a significant effect partially and have a positive relationship to gross domestic product with a probability value of 0.000 and the coefficient 0.277285 . This is consistent with the hypothesis that is predetermined and the study received $\mathrm{HI}$ and reject $\mathrm{HO}$.

2. Inflation does not affect the gross domestic product by 0652 and a probability value coefficient -0.000516 . This is not consistent with the hypothesis that is predetermined and the study received $\mathrm{HO}$ and reject $\mathrm{H} \mathrm{l}$.

3. Exchange Rate USD significant effect partially and have a positive relationship to gross domestic product with a probability value of 0.000 and the coefficient 0.123414 . This is consistent with the hypothesis that is predetermined and the study received $\mathrm{H} \mathrm{l}$ and reject $\mathrm{HO}$.

4. World Oil Prices, Inflation and Exchange Rate USD significant effect simultaneously and have a positive relationship to gross domestic product with a probability value of 0.000 and the coefficient of determination (R2) 0.987152 . This is consistent with the hypothesis that is predetermined and the study received $\mathrm{Hl}$ and reject $\mathrm{HO}$.

\section{Suggestion}

Based on the steps that have been performed in this study, the suggestions to the authors give is:

1. For academics, it is expected for the next researcher to add other study variables that affect gross domestic product in oil-exporting countries such as government spending and monetary policies and fiscal

2. To policy makers Islamic Cooperation Organization to be able to control the large number of economies that rely on the sector as it will be susceptible to factors that could damage the economy. And be able to apply the rules strictly and in line with the vision and mission when OKI first established.

3. The OIC member countries are included in the oil-exporting countries are expected to implement policies regarding the problems of oil and gas commodities as a whole and not to give priority to political interests only.

\section{References}

[1] McEachern, William. 2000 Macroeconomic: Contemporary Approaches. Jakarta: Four Salemba. 
[1] Ahmad, Khursid. 1997. Economic Development in the Perspective of Islam, in Ethics of Political Economy. Jakarta: Risalah Gusti.

[2] Anshori, Mucslich and Sri Iswati. 2009. Quantitative Research Methodology. Surabaya: Publishing and Printing Center Airlangga University.

[3] Boyes, William and Michael Melvin. (2008). Macroeconomics. Boston: Houghton Mifflin Company.

[4] BP. 2017 BP Statistical Review of World Energy. London.www.bp.com/statisticalreview. (accessed on May 28, 2018).

[5] Corden, W. Max. Too Sensational 2002. On the Choice of Exchange Rate regimes. Massachusetts: MIT Press,

[6] Gujarati, Damodar N., 2004. Basic Econometrics. Fourth edition. Singapore. McGraw-Hill Inc.

[7] Karim, A. 2007. Macroeconomic Adiwarman Islam. Jakarta: King Grafindo Persada.

[8] KEMENAG RI. 2012.Qur'an Translation, Bekasi: Good Cipta Segara.

[9] Krugman, Paul and Obstfeld, Maurice, 2004. International Economic Theory and Policy Publisher Harper Collins. Linguist. DR. Faisal Basri, SE MSC, Jakarta: PT Gramedia Group Index.

[10] Mankiw N, Gregory. 2003. Macroeconomics, 5th Edition. New York: Worth Publishers

[11] Mannan, MA 1997. Economic Theory and Practice of Islam, trans. M. Nastngin. Yogyakarta: Bhakti Wagf Fund.

[12] Rahardja, prathama and Manurung, Mandala. 2008. Macroeconomic Theory. Fourth Edition. Jakarta; Issuing Faculty of Economics, University of Indonesia.

[13] Sukirno, Sadono. 2000. Macroeconomic Modern. First Edition First Edition. Jakarta: King Grafindo Persada

[14] Sobel, Russell S. et. al. (2009). Macroeconomics: Private and Public Choice, 13th edition. Canada: CENCAGE Learning.

[15] Todaro, M. 2000. Economic Development 2. Fifth Edition. Jakarta: PT. Earth Literacy. 